\title{
A quasi-direct methanol fuel cell system based on blend polymer membrane electrolytes
}

\author{
Li, Qingfeng; Hjuler, Hans Aage; Hasiotis, C.; Kalletsis, J.K.; Kontoyannis, C.G.; Bjerrum, Niels
}

Published in:

Electrochemical and Solid-State Letters

Link to article, DOI:

$10.1149 / 1.1473335$

Publication date:

2002

Document Version

Publisher's PDF, also known as Version of record

Link back to DTU Orbit

Citation (APA):

Li, Q., Hjuler, H. A., Hasiotis, C., Kalletsis, J. K., Kontoyannis, C. G., \& Bjerrum, N. (2002). A quasi-direct methanol fuel cell system based on blend polymer membrane electrolytes. Electrochemical and Solid-State Letters, 5(6), A125-A128. https://doi.org/10.1149/1.1473335

\section{General rights}

Copyright and moral rights for the publications made accessible in the public portal are retained by the authors and/or other copyright owners and it is a condition of accessing publications that users recognise and abide by the legal requirements associated with these rights.

- Users may download and print one copy of any publication from the public portal for the purpose of private study or research.

- You may not further distribute the material or use it for any profit-making activity or commercial gain

- You may freely distribute the URL identifying the publication in the public portal 


\title{
A Quasi-Direct Methanol Fuel Cell System Based on Blend Polymer Membrane Electrolytes
}

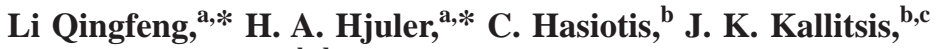 \\ C. G. Kontoyannis, ${ }^{\text {b,d }}$ and N. J. Bjerrum ${ }^{\mathrm{a}, *, \mathrm{z}}$ \\ ${ }^{a}$ Materials Science Group, Department of Chemistry, Technical University of Denmark, \\ DK-2800 Lyngby, Denmark \\ ${ }^{b}$ Institute of Chemical Engineering and High Temperature Chemical Processes, GR-265 00 Patras, Greece \\ ${ }^{c}$ Department of Chemistry, ${ }^{d}$ Department of Pharmacy, University of Patras, GR-265 00 Patras, Greece
}

On the basis of blend polymer electrolytes of polybenzimidazole and sulfonated polysulfone, a polymer electrolyte membrane fuel cell was developed with an operational temperature up to $200^{\circ} \mathrm{C}$. Due to the high operational temperature, the fuel cell can tolerate $1.0-3.0 \mathrm{vol} \% \mathrm{CO}$ in the fuel, compared to less than $100 \mathrm{ppm} \mathrm{CO}$ for the Nafion-based technology at $80^{\circ} \mathrm{C}$. The high CO tolerance makes it possible to use the reformed hydrogen directly from a simple methanol reformer without further $\mathrm{CO}$ removal. That both the fuel cell and the methanol reformer operate at temperatures around $200^{\circ} \mathrm{C}$ opens the possibility for an integrated system. The resulting system is expected to exhibit high power density and simple construction as well as efficient capital and operational cost. (C) 2002 The Electrochemical Society. [DOI: 10.1149/1.1473335] All rights reserved.

Manuscript submitted October 8, 2001; revised manuscript received February 15, 2002. Available electronically April 4, 2002.

As an efficient and environmentally friendly technology, fuel cells are expected to provide a practical form of power generation. Recent advances in the polymer electrolyte membrane fuel cell (PEMFC) have stimulated increased interest in passenger fuel cell driven vehicles. ${ }^{1}$ The currently well-developed PEMFC technology is based on perfluorosulfonic acid polymer membranes (e.g., Nafion) as electrolyte. According to the types of fuel, the PEMFCs can be classified as direct hydrogen fuel cell (DHFC), reformed hydrogen fuel cell (RHFC), and direct methanol fuel cell (DMFC).

With pure hydrogen as fuel, the DHFC exhibits a single-cell performance of higher than $0.5 \mathrm{~W} / \mathrm{cm}^{2}$ under atmospheric pressure or over $1.0 \mathrm{~W} / \mathrm{cm}^{2}$ at higher pressures. The DHFC stacks have achieved specific power output as high as $1.3 \mathrm{~kW} / \mathrm{L}$. This technology has weight, volume, and other features competitive with internal-combustion-engine propulsion systems. The direct use of pure hydrogen as fuel reduces vehicle complexity and eliminates the need to develop reliable on-board chemical processors. However, the development of a new hydrogen infrastructure faces unsolved technological problems with economic uncertainties such as compact and lightweight hydrogen storage and hydrogen supply, distribution, and refueling systems.

Technically, the necessity for pure hydrogen as fuel arises from the poisoning effect of the electrode catalysts by fuel impurities, e.g., CO. This CO poisoning effect is temperature dependent. ${ }^{2}$ The conductivity of the currently available polymer membranes, e.g., Nafion is dependent on the presence of water to solvate the protons from the sulfonic acid groups. Consequently, the operational temperature is limited to be $<100^{\circ} \mathrm{C}$ at atmospheric pressure. At $80^{\circ} \mathrm{C}$, a typical temperature for PEMFC operation, platinum catalysts tolerate only 10-20 ppm CO.

Use of methanol is an efficient and economical way of bringing hydrogen to a fuel cell system since its storage and refueling need little infrastructure change. Currently, methanol is used in an indirect way, i.e., by reforming. The reformate gas contains hydrogen, carbon dioxide, carbon monoxide, and residual water and methanol as well. ${ }^{3-6}$ Due to the above-mentioned $\mathrm{CO}$ poisoning effect, considerable efforts have been made to develop CO-tolerant electrocatalysts with PtRu alloys as the most promising candidates, ${ }^{7}$ although alternative approaches such as air-bleeding ${ }^{8}$ or addition of hydrogen peroxide to the fuel humidifier ${ }^{9}$ were also proposed. Even with PtRu catalysts, however, a significant performance loss is still observed at a $\mathrm{CO}$ concentration above $100 \mathrm{ppm}$ at operational temperatures around $80^{\circ} \mathrm{C}$. Therefore careful purification of the reformed hydro-

\footnotetext{
* Electrochemical Society Active Member

z E-mail: njb@kemi.dtu.dk
}

gen is necessary to remove CO. This is carried out by water-gas shift reaction, preferential oxidation, membrane separation, or methanation. The CO removal considerably increases the size and cost of the fuel processing system. For a small dynamic load as in a vehicle, the main challenge for an on-board processing system is the complexity, which not only requires increased cost, size, and volume but also reduces the start-up time and transient response capacity of the system. Such a fuel processing system generally covers $40-50 \%$ of the cost for a fuel cell power system and the CO-cleanup unit counts for the major part of weight, volume, and cost of the fuel processing system.

Direct use of methanol as a fuel is a preferable option for propulsion of vehicles. However, the DMFC technology is far from satisfactory, mainly because of two technical challenges. ${ }^{10}$ First, the anodic catalyst is not sufficiently active, resulting in high anodic overpotential loss ( $c a .350 \mathrm{mV}$ compared to $c a$. $60 \mathrm{mV}$ for hydrogen). Second, the currently available solid polymer electrolytes, e.g., Nafion have a large methanol crossover rate, which results in not only waste of fuel but also a considerably lowered energy efficiency and cell performance.

Provided that the need for a fuel reformer, which is associated with increased volume and weight and reduced efficiency, is eliminated, it is believed that a power density as low as $0.2 \mathrm{~W} / \mathrm{cm}^{2}$ at a cell voltage of $0.5 \mathrm{~V}$ for a DMFC would be competitive with a power density of $0.5-0.6 \mathrm{~W} / \mathrm{cm}^{2}$ for a DHFC or a RHFC. However, even such a low power density target can be achieved only for a DMFC at high operational pressures (3-5 bar) and high noble metal loadings $\left(2.0-8.0 \mathrm{mg} / \mathrm{cm}^{2}\right) .{ }^{10}$

An active subject in the field of PEMFC is the temperatureresistant solid polymer membrane electrolytes such as acid-doped polybenzimidazole (PBI), ${ }^{11,12}$ sulfonated hydrocarbons,${ }^{13}$ and their composites with inorganic proton conductors. ${ }^{14}$ In our previous work, blends of PBI with sulfonated polysulfone (SPSF) have been prepared. ${ }^{15-17}$ After impregnation with phosphoric acid, the PBISPSF blend membranes possess higher ionic conductivity and better mechanical properties than pure PBI in a temperature range up to $200^{\circ} \mathrm{C}$. At such an elevated temperature, a PEMFC is expected to tolerate 20,000-30,000 ppm CO, compared to $<100 \mathrm{ppm} \mathrm{CO}$ for the Nafion-based technology at $80^{\circ} \mathrm{C}$. This high $\mathrm{CO}$ tolerance makes it possible to operate the fuel cell with reformed hydrogen directly from a methanol reformer and therefore opens the possibility for an integrated system. ${ }^{18}$ The present work demonstrates this possibility.

\section{Experimental}

Polybenzimidazole (PBI) is a poly[2,2' - $(m$-phenylene $)-5,5^{\prime}$ bibenzimidazole] product. The polymer powder $(-100$ mesh) was first mixed with dimethylacetamide (DMAc) and introduced into a 
stainless steel bomb reactor. $2 \mathrm{wt} \% \mathrm{LiCl}$ was added as the stabilizer. Oxygen was excluded from the bomb by bubbling argon through the mixture solution for $2 \mathrm{~h}$. The bomb reactor was then closed and placed in a rotating oven at $250^{\circ} \mathrm{C}$ for $3 \mathrm{~h}$. The solution was filtered and diluted for membrane casting.

SPSF was prepared by sulfonation of polysulfone with chlorosulfonic acid as the sulfonated agent in a dichloroethane solution. ${ }^{13,14}$ The sodium salt was prepared by neutralizing the solution of SPSF with a methanol solution of sodium hydroxide under vigorous stirring. The precipitated product was filtered, washed, and dried at $100^{\circ} \mathrm{C}$ under high vacuum.

Blends of PBI/SPSF were obtained by mixing the two polymer solutions $(1 \% \mathrm{w} / \mathrm{v})$ in DMAc at the desired ratio for $1.5 \mathrm{~h}$ at $160^{\circ} \mathrm{C}$. The blend membranes were cast on a glass plate. The thickness of the membranes was varied by controlling the volume of the solution, ranging from 80 to $110 \mu \mathrm{m}$. The major part of the solvent was evaporated in a ventilated oven in a temperature range from 80 to $120^{\circ} \mathrm{C}$. Membranes were then washed with distilled water at $80^{\circ} \mathrm{C}$ and further dried at $190^{\circ} \mathrm{C}$ under vacuum for 3 days. The PBI/SPSF blend membranes were then doped with phosphoric acid at a doping level of $c a .5 \mathrm{~mol} \mathrm{H}_{3} \mathrm{PO}_{4}$ per average repeating unit of the blend polymers.

Platinum catalysts $(20 \% \mathrm{Pt})$ supported on carbon black (Vulcan $\mathrm{XC}-72 \mathrm{R}$, Cabot) were prepared by chemical reduction of platinum chloroacid $\left(\mathrm{H}_{2} \mathrm{PtCl}_{6}\right)$. The catalysts were applied onto the wetproofed carbon paper (Toray TGP-H-120) by a tape-casting technique. The obtained gas-diffusion electrodes were then impregnated with the blend polymer solution. After drying at $190^{\circ} \mathrm{C}$ for $c a .1 \mathrm{~h}$, the electrodes were doped with 10 wt $\%$ phosphoric acid by brushing. Assemblies from the impregnated electrodes and the doped polymer membranes were made by hot-press at $150^{\circ} \mathrm{C}$ for $10 \mathrm{~min}$.

A single fuel cell $\left(5 \mathrm{~cm}^{2}\right)$ was made of graphite plates with gas channels. Two aluminum end plates with attached heaters were used to clamp the graphite plates. Fuel and oxidant gases were supplied by mass flow controllers. For evaluating the $\mathrm{CO}$ tolerance, a mixture of 97 vol \% hydrogen and 3 vol \% carbon monoxide was premade. Mixed gas of other compositions was obtained by using mass flowmeters and controllers. Oxygen, under atmospheric pressure at a flow rate of $40 \mathrm{~mL} \mathrm{~min}^{-1} \mathrm{~cm}^{-2}$, was used as the oxidant.

Low temperature, low pressure catalysts for methanol reforming were prepared from copper, zinc, and alunimun nitrates with a molar ratio of 2:1:0.4. The mixed oxides were coprecipitated by sodium carbonate at $80^{\circ} \mathrm{C}$, dried after filtering and washing, and finally calcined at $400{ }^{\circ} \mathrm{C} .{ }^{19}$ The granulated powder was then pelleted.

A DMFC system was modified by filling the fuel vaporizer with the methanol reforming catalyst pellets. The vaporizer or reformer consists of a stainless steel tube and external heating elements. A stainless steel screen ( 40 mesh) was fixed across the tube at the bottom end to support the catalysts. About $40 \mathrm{~g}$ of the catalyst pellets were crushed and packed uniformly in the reaction zone about $22 \mathrm{~mm}$ in diam and $135 \mathrm{~mm}$ long. The catalysts were reduced slowly by a methanol/water feed at temperatures around $150^{\circ} \mathrm{C}$ overnight. A premixed liquid of water and methanol in molar ratio of 1:1 was preheated to vapor before entering the reaction zone. The reformed gas from the reactor, first passed through water to remove the residue methanol, was directly fed into the fuel cell without further purification with respect to the CO removal.

\section{Results and Discussion}

Figure 1 shows the cell voltage and power density as a function of current density of the high temperature polymer membrane electrolyte fuel cell under atmospheric pressure at $200^{\circ} \mathrm{C}$. The electrodes were with a Pt/C catalyst at loading of $0.45 \mathrm{mg} / \mathrm{cm}^{2}$. The membrane of $75 \% \mathrm{PBI}$ and $25 \% \mathrm{SPSF}_{36}$ (with a sulfonation degree of $36 \%$ ) was doped with phosphoric acid at a doping level of $520 \mathrm{~mol} \%$ $\mathrm{H}_{3} \mathrm{PO}_{4}$ (i.e., $5.2 \mathrm{~mol} \mathrm{H}_{3} \mathrm{PO}_{4}$ per average repeating unit of polymers).

With pure hydrogen as fuel, a cell performance of $670 \mathrm{~mA} / \mathrm{cm}^{2}$ was obtained at $0.6 \mathrm{~V}$, corresponding to a power density

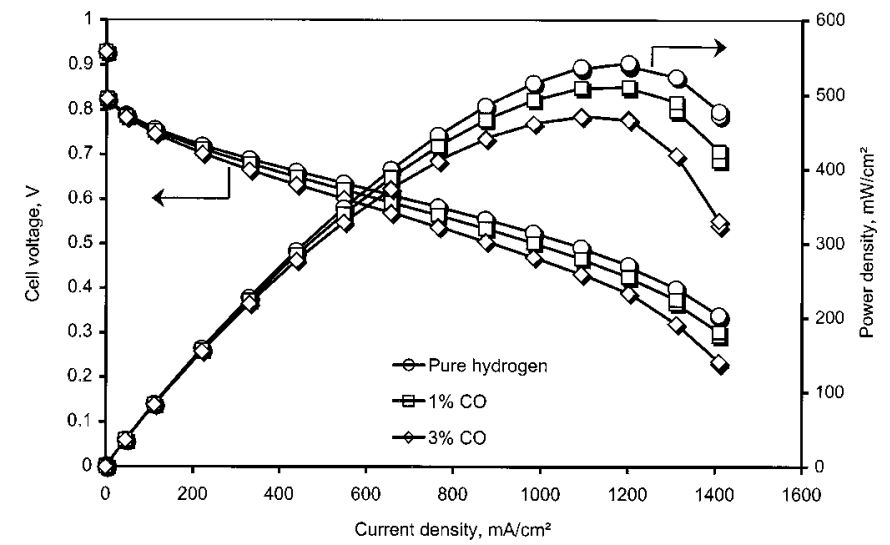

Figure 1. Cell voltage and power density vs. current density of the high temperature polymer membrane electrolyte fuel cell under atmospheric pressure at $200^{\circ} \mathrm{C}$. Electrodes were prepared with a platinum loading of 0.45 $\mathrm{mg} / \mathrm{cm}^{2}$. The membrane comprised $75 \%$ PBI and $25 \%$ SPSF (sulfonation degree $36 \%$ ), doped with $520 \mathrm{~mol} \% \mathrm{H}_{3} \mathrm{PO}_{4}$. The fuel gas was pure hydrogen and hydrogen containing 1.0 and $3.0 \% \mathrm{CO}$ as indicated in the figure.

$>400 \mathrm{~mW} / \mathrm{cm}^{2}$. The maximum power density of $540 \mathrm{~mW} / \mathrm{cm}^{2}$ was observed at the current density of $1090 \mathrm{~mA} / \mathrm{cm}^{2}$. This performance is close to that for a Nafion-based PEMFC at $80^{\circ} \mathrm{C}$, although electrodes and membrane electrode assemblies (MEAs) have not been well optimized.

Many investigators have studied the poisoning effect of platinum catalysts by carbon monoxide extensively. This poisoning effect has been attributed to the strong adsorption of $\mathrm{CO}$ on the catalyst surface with linear and/or multibonding. As a consequence, the active sites of catalyst for hydrogen electro-oxidation are greatly reduced since the adsorbed $\mathrm{CO}$ is inert in the potential regions where the hydrogen anode operates. With platinum as the anodic catalyst at a typical operational temperature of $80^{\circ} \mathrm{C}$ for Nafion-based PEMFCs, a $\mathrm{CO}$ content as low as $10-20 \mathrm{ppm}$ in the fuel steam results in a significant loss in the PEMFC performance.

The CO-poisoning effect is temperature dependent. At $130^{\circ} \mathrm{C}$, for example, platinum-based catalysts can tolerate up to $1000 \mathrm{ppm} \mathrm{CO}$, compared to only $10 \mathrm{ppm}$ at $80^{\circ} \mathrm{C}^{2}$ As shown in Fig. 1, an operational temperature around $200^{\circ} \mathrm{C}$ enables the PEMFC to tolerate up to $3.0 \% \mathrm{CO}$, i.e., $30,000 \mathrm{ppm} \mathrm{CO}$. As seen from Fig. 1, hydrogen containing 1.0 and $3.0 \%$ carbon monoxide results in a voltage decrease from 0.61 to 0.59 and $0.57 \mathrm{~V}$ at $660 \mathrm{~mA} / \mathrm{cm}^{2}$, respectively. This corresponds to a power density decrease from 400 to 390 and $375 \mathrm{~mW} / \mathrm{cm}^{2}$ at $660 \mathrm{~mA} / \mathrm{cm}^{2}$, i.e., a performance loss of about 3 and $7 \%$ with the $\mathrm{CO}$ content of 1.0 and $3.0 \%$, respectively. At a current density of $1090 \mathrm{~mA} / \mathrm{cm}^{2}$, the maximum power density decreases from 540 to 510 and $470 \mathrm{~mW} / \mathrm{cm}^{2}$ when the fuel stream is switched from pure hydrogen to hydrogen containing 1.0 and $3.0 \%$ $\mathrm{CO}$, respectively.

The high tolerance to $\mathrm{CO}$ by the high temperature PEMFC technology, being 2000-3000 times higher than that for the Pt/C catalysts at $80^{\circ} \mathrm{C}$, allows the high temperature PEMFC to operate with reformed methanol directly from a simple reformer. This decisively simplifies the fuel processing system by eliminating the $\mathrm{CO}$ removal processors. The resulting power system therefore is much more compact, light, and cost-efficient with enhanced power density and improved transient performance. These features are of special importance for automobile applications. For demonstrating the feasibility, a DMFC test system was modified by filling the methanol vaporizer with methanol-reforming catalysts, as shown in Fig. 2. By feeding a mixture of methanol and water in a molar ratio of $1: 1$, the methanol reformer is operated from 190 to $220^{\circ} \mathrm{C}$, close to the operational temperature of the PEMFC. 


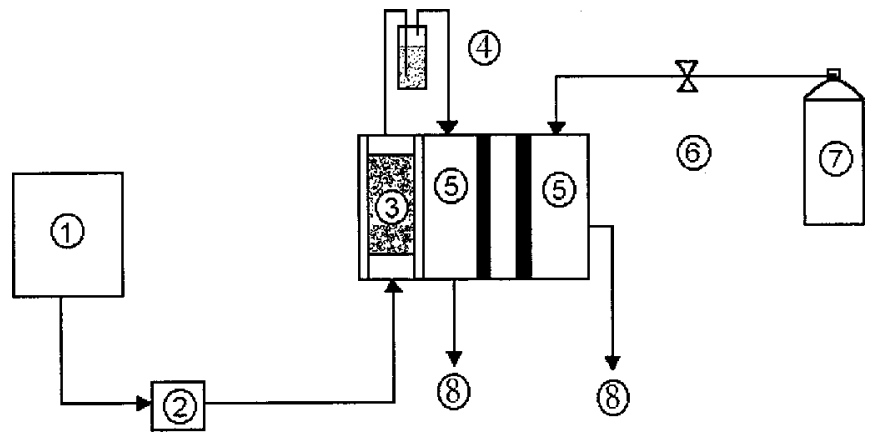

Figure 2. Schematic diagram of the fuel cell test setup. (1) mixture of methanol and water; (2) pump; (3) vaporizer or reformer when filled with catalysts; (4) water condenser; (5) fuel cell; (6) valve; (7) oxygen; and (8) exhaust.

At temperatures higher than $160^{\circ} \mathrm{C}$, methanol and steam react to form a hydrogen-rich gas with the help of the $\mathrm{Cu} / \mathrm{ZnO} / \mathrm{Al}_{2} \mathrm{O}_{3}$ catalyst. ${ }^{7}$ The overall reaction can be written as

$$
\mathrm{CH}_{3} \mathrm{OH}+\mathrm{H}_{2} \mathrm{O}=\mathrm{CO}_{2}+3 \mathrm{H}_{2}
$$

which is the sum of the methanol decomposition and the water-gas shift

$$
\begin{gathered}
\mathrm{CH}_{3} \mathrm{OH}=\mathrm{CO}+2 \mathrm{H}_{2} \\
\mathrm{CO}+\mathrm{H}_{2} \mathrm{O}=\mathrm{CO}_{2}+\mathrm{H}_{2}
\end{gathered}
$$

In the presence of water in stoichiometric amounts from 190 to $220^{\circ} \mathrm{C}$, it is confirmed here that the product gas is close in composition to that of Reaction 1 . On a volume basis, the obtained gas contains about $74.5 \%$ hydrogen, $24.5 \% \mathrm{CO}_{2}$, and less than $1.0 \%$ $\mathrm{CO}$, besides some remaining methanol and water. This is in good agreement with the results by Amphlett et al., ${ }^{4}$ who reported that the $\mathrm{CO}$ concentration in the product gas is less than $1 \%$ at less than $220^{\circ} \mathrm{C}$ under atmospheric pressure.

Figure 3 shows the fuel cell performance with either pure hydrogen or the methanol reformate at $200^{\circ} \mathrm{C}$. Platinum catalyst is used for both anode and cathode, at a loading of about $0.45 \mathrm{mg} / \mathrm{cm}^{2}$. The methanol reformer is operated at $200^{\circ} \mathrm{C}$, the same as the fuel cell. This reformer-fuel cell system has been tested for only 3 days of 6-7 $h$ of operation each day. The fuel cell has been switched between hydrogen and the reformate fuel twice a day. No significant degradation in the performance has been observed.

Throughout the whole current density range, up to $1.3 \mathrm{~A} / \mathrm{cm}^{2}$, a voltage loss about $30-70 \mathrm{mV}$ is observed by using the methanol reformate instead of pure hydrogen. As expected from the COtolerance measurement, carbon monoxide of less than $1 \%$ in the reformed gas does not result in any significant performance loss. The observed performance loss is primarily due to the dilution of the fuel gas by carbon dioxide.

At a cell voltage of $0.6 \mathrm{~V}$, a power density of $340 \mathrm{~mW} / \mathrm{cm}^{2}$ was obtained by using the methanol reformate gas as fuel. The maximum power output of $494 \mathrm{~mW} / \mathrm{cm}^{2}$ was achieved at the cell voltage of 0.4 $\mathrm{V}$ (current density of $1260 \mathrm{~mA} / \mathrm{cm}^{2}$ ). This was achieved using $0.45 \mathrm{mg} / \mathrm{cm}^{2} \mathrm{Pt}$ at both anode and cathode and the oxygen cathode under atmospheric pressure. It may not be straightforward to compare, however, Ren et al. ${ }^{20}$ reported, using Nafion 112 membranes, $2.2 \mathrm{mg} / \mathrm{cm}^{2} \mathrm{Pt}-\mathrm{RuO}_{x}$ catalyst at anode, $2.3 \mathrm{mg} / \mathrm{cm}^{2}$ Pt black at cathode, oxygen under 5 atm at $130^{\circ} \mathrm{C}$, a DMFC peak power output around $400 \mathrm{~mW} / \mathrm{cm}^{2}$ at a cell voltage about $0.4 \mathrm{~V}$ (current density about $950 \mathrm{~mA} / \mathrm{cm}^{2}$ ). At a cell voltage around $0.6 \mathrm{~V}$, however, the DMFC gave a power output around $200 \mathrm{~mW} / \mathrm{cm}^{2}$.

More experiments were carried out with the methanol reforming from 190 to $220^{\circ} \mathrm{C}$. In this temperature range, the conversion of

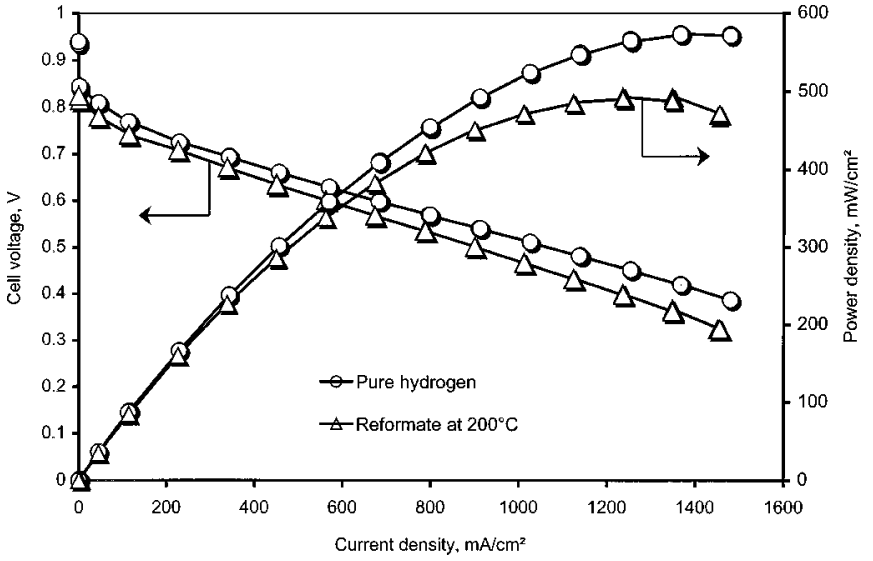

Figure 3. Cell voltage and power density vs. current density of the high temperature polymer membrane electrolyte fuel cell under atmospheric pressure at $200^{\circ} \mathrm{C}$. Electrodes were prepared with a platinum loading of 0.45 $\mathrm{mg} / \mathrm{cm}^{2}$. The membrane comprised $75 \%$ PBI and $25 \%$ SPSF (sulfonation degree $36 \%$ ), doped with $520 \mathrm{~mol} \% \mathrm{H}_{3} \mathrm{PO}_{4}$. The fuel gas was pure hydrogen and reformed hydrogen-rich gas directly from a methanol reformer. The reformer operated at $200^{\circ} \mathrm{C}$ with a mixture feeding of methanol and water in a molar ratio $1: 1$

methanol to hydrogen may not be complete. However, no attempt has been made to determine the methanol conversion and reformed gas composition as a function of temperature. The possible residue methanol in the reformed gas is condensed by passing through a condenser, which is filled with water and kept at room temperature. No significant performance difference is observed in the studied temperature range of methanol reforming.

That both the fuel cell and the simply combined methanol reformer operate at the same temperature around $200^{\circ} \mathrm{C}$ opens the possibility for an integrated system. The possible on-site reforming of methanol allows one to construct a quasi-direct methanol fuel cell (QDMFC). In a conventional DMFC with vapor feed, a vaporizer is needed anyway, since the temperature of PEMFC is low. As a comparison, QDMFC needs only to fill the methanol vaporizer with reforming catalysts. Concerning weight, volume, and start-up time and transient response, this QDMFC is comparable with a DMFC system. This QDMFC can operate with a much lower noble metal loading but at a much higher power density than that of a DMFC.

With respect to fuel storage, processing, and fuel cell features, a

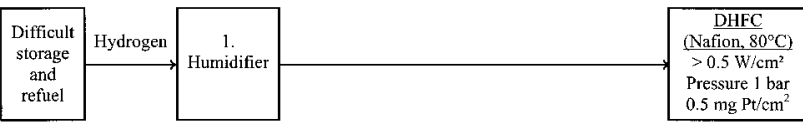

B
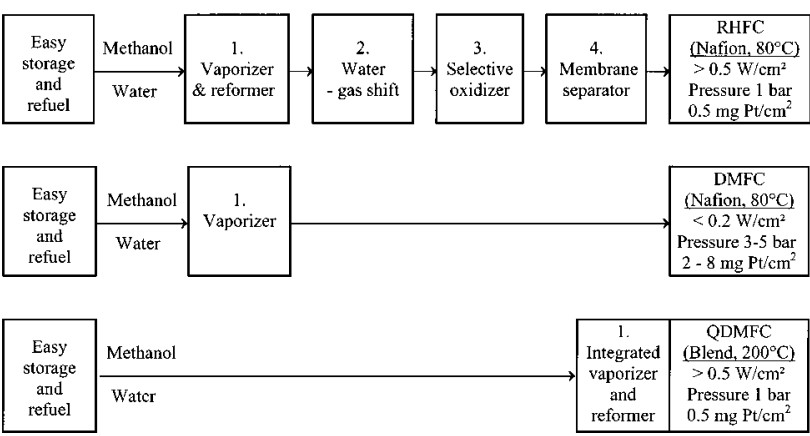

Figure 4. Schematic presentation of four types of PEMFC systems. (A) DHFC, (B) RHFC, (C) DMFC, and (D) QDMFC. 
comparison of three types of Nafion-based PEMFCs (DHFC, RHFC, and DMFC) as well as the QDMFC is summarized schematically in Fig. 4.

DHFC has high power density (over $500 \mathrm{~mW} / \mathrm{cm}^{2}$ ), needs limited fuel processing (humidification), but involves complicated fuel storage. RHFC exhibits high power density (over $500 \mathrm{~mW} / \mathrm{cm}^{2}$ ), easy fuel storage but complicated fuel processing system. DMFC involves easy fuel storage and limited fuel processing (evaporation) but has a rather low power density (around $200 \mathrm{~mW} / \mathrm{cm}^{2}$ ) even at high operational pressure and high catalyst loading. As a comparison, QDMFC takes advantages of the high power density (over $400 \mathrm{~mW} / \mathrm{cm}^{2}$ ) for DHFC or RHFC but avoids either the difficult fuel storage for DHFC or the complicated and expensive fuel processing system for RHFC. The QDMFC technology maintains advantages of the easy fuel storage and simple fuel processing for DMFC but gives a considerably higher power density compared to the current DMFC technology.

This integration is expected to give the overall power system advanced features including higher efficiency, small size, light weight, simple construction and operation, and efficient capital and operational cost. High reliability, less maintenance, and better transient response capacities can also be expected as the potential features of the technology.

\section{Conclusions}

On the basis of the temperature-resistant polymer membrane electrolytes, advanced PEMFCs can operate at temperatures up to $200^{\circ} \mathrm{C}$. The fuel cell exhibits a performance close to a Nafion-based direct hydrogen fuel cell, i.e., over $0.4 \mathrm{~W} / \mathrm{cm}^{2}$ at a cell voltage of 0.6 $\mathrm{V}$ under atmospheric pressure and with a noble catalyst loading of $0.45 \mathrm{mg} / \mathrm{cm}^{2}$. Due to the high operational temperature, this fuel cell can tolerate 1.0-3.0 vol \% CO in the fuel (i.e., 10,000-30,000 ppm $\mathrm{CO}$, compared to less than $100 \mathrm{ppm} \mathrm{CO}$ for the Nafion-based technology at $80^{\circ} \mathrm{C}$ ). This high $\mathrm{CO}$ tolerance makes it possible to use the reformed methanol directly from a simple reformer without further $\mathrm{CO}$ removal. The operational temperature of the fuel cell at $200^{\circ} \mathrm{C}$ is high enough for methanol reforming. This allows the fuel cell to be integrated with a simple methanol reformer.

\section{Acknowledgment}

Part of this work has received financial support from the European Commission in the framework of the Non Nuclear Energy Program JOULE III (contract no. JOE3CT970045).

Technical University of Denmark assisted in meeting the publication costs of this article.

\section{References}

1. S. J. C. Cleghorn, X. Ren, T. E. Springer, M. S. Wilson, C. Zawodzinski, T. A. Zawodzinski, and S. Gottesfeld, Int. J. Hydrogen Energy, 22, 1137 (1997).

2. X. Gang, Li Qingfeng, H. A. Hjuler, R. W. Berg, and N. J. Bjerrum, J. Electrochem. Soc., 142, 2890 (1995).

3. C. E. Thomas, Int. J. Hydrogen Energy, 23, 507 (1998).

4. J. C. Amphlett, K. A. M. Creber, J. M. Davis, R. F. Mann, B. A. Peppley, and D. M. Stokes, Int. J. Hydrogen Energy, 19, 131 (1994).

5. J. C. Amphlett, R. F. Mann, and B. A. Peppley, Int. J. Hydrogen Energy, 21, 673 (1996).

6. B. A. Peppley, J. C. Amphlett, L. M. Kearns, and R. F. Mann, Appl. Catal., A, 179, 21 (1999); 179, 31 (1999)

7. T. J. Schmidt, M. Noeske, H. A. Gasteiger, and R. J. Behm, J. Electrochem. Soc., 145, 925 (1998).

8. S. Gottesfeld and J. Pafford, J. Electrochem. Soc., 135, 2651 (1988).

9. V. M. Schmidt, H. F. Oetjen, and J. Divisek, J. Electrochem. Soc., 144, L237 (1997).

10. M. P. Hogarth and G. A. Hards, Eur. Fuel Cell News, 4, 14 (1997).

11. J. S. Wainright, J.-T. Wang, D. Weng, R. F. Savinell, and M. Litt, J. Electrochem. Soc., 142, L121 (1995)

12. L. Qingfeng, H. A. Hjuler, and N. J. Bjerrum, J. Appl. Electrochem., 31, 773 (2001).

13. M. Rikukawa and K. Sanui, Prog. Polym. Sci., 25, 1463 (2000).

14. G. Alberti and M. Casciola, Solid State Ionics, 145, 3 (2001)

15. V. Deimede, G. A. Voyiatzis, J. K. Kallitsis, L. Qingfeng, and N. J. Bjerrum, Macromolecules, 33, 7609 (2000).

16. C. Hasiotis, V. Deimede, and C. Kontoyannis, Electrochim. Acta, 46, 2401 (2001).

17. C. Hasiotis, L. Qingfeng, V. Deimede, J. K. Kallitsis, C. G. Kontoyannis, and N. J. Bjerrum, J. Electrochem. Soc., 148, A513 (2001).

18. N. J. Bjerrum, L. Qingfeng, and H. A. Hjuler, Danish Pat. Appl. PA2001 00213 and Int. Pat. Publ. WO 01/18894 A2.

19. A. B. Stiles, Catalyst Manufacture, Laboratory and Commercial Preparations, Marcel Dekker, Inc., New York (1983).

20. X. Ren, M. S. Wilson, and S. Gottesfeld, J. Electrochem. Soc., 143, L12 (1996). 